\title{
ОСОБЛИВОСТІ ОЦІНЮВАННЯ ІНВЕСТИЦІЙНОї СТРАТЕГІЇ АВТОТРАНСПОРТНИХ ПІДПРИЕМСТВ
}

\section{FEATURES OF INVESTMENT STRATEGY EVALUATION OF MOTOR TRANSPORT ENTERPRISES}

\author{
Гайдай Ганна Григорівна \\ старший викладач, \\ Національний транспортний університет \\ ORCID: https://orcid.org/0000-0002-1731-9056
}

\author{
Haidai Hanna \\ National Transport University
}

В дані статті розглядається методика оцінювання інвестиційної стратегії, як один з найважливіших етапів при їі фрормуванні. Проаналізовано та систематизовано сучасні методи та підходи щодо оцінки інвестиційної стратегії. В основу запропонованої методики покладено визначення якості інвестиційної стратегії, як найвищої характеристики процесу при її фрормуванні. Для розрахунку якості інвестиційної стратегії побудована фрормула, яка відображає математичну залежність оцінки якості від ефективності та ступеню ризику як головних параметрів, що дає можливість побувати тривимірну модель якості інвестиційної стратегії. Крім того, фрормула враховує вплив фракторів (коесіцієнтів) зовнішнього бізнес-середовища: макросередовища, мікросередовища та мезосередовища/конкурентного середовища. Запропонована методика дозволяє отримати ефрективний інструмент аналізу інвестиційної стратегії та має практичне значення для автотранспортних підприємств при орормуванні інвестиційної стратегії.

Ключові слова: інвестиційна стратегія, оцінювання, фрактори впливу, конкурентоспроможність, ефективність, ступінь ризику, тривимірна модель.

В данной статье рассматривается методика оценки инвестиционной стратегии, как один из важнейших этапов при ее формировании. Проанализированы и систематизированы современные методы и подходы к вопросу оценки инвестиционной стратегии. В основу предложенной методики положено определение качества инвестиционной стратегии, как наивысшей характеристики процесса при ее формировании. Для расчета качества инвестиционной стратегии построена формула, которая отображает математическую зависимость оценки качества от эффрективности и степени риска как главных параметров, что дает возможность построить трехмерную модель качества инвестиционной стратегии. Кроме этого, формула включает влияние фракторов (коэфффициентов) внешнего бизнес-окружения: макроокружение, микроокружение, мезоокружение/ конкурентное окружение. Предложенная методика позволяет получить эфффективный инструмент для анализа инвестиционной стратегии и имеет практическое значение для автотранспортных предприятий при ее фороировании.

Ключевые слова: инвестиционная стратегия, оценка, фракторы влияния, конкурентоспособность, эффрективность, степень риска, трехмерная модель.

This article describes the methodology for evaluating an investment strategy as one of the most important stages in its formation. Modern methods and approaches to evaluation of investment strategy are analyzed and systematized. The proposed methodology is based on the definition of the quality of the investment strategy as the highest characteristic of the process, which depends on certain basic parameters: efficiency and degree of risk. To calculate the quality of the investment strategy, a formula is constructed that reflects the mathematical dependence of the quality assessment as a function, on the efficiency and degree of risk, as the main parameters, which makes it possible to visit a $3 \mathrm{~d}$ model of the quality of the investment strategy. At the same time, quality has a direct proportional dependence on efficiency and inversely proportional dependence on the degree of risk. In turn, the quality parameters of the investment strategy are of integral origin and depend on the assessment of single figures (factors). In addition, the formula takes into account the influence of factors (coefficients) of the external business environment: macro-environment, micro-environment and meso environment/competitive environment both on efficiency and risk degree. The effectiveness of the investment strategy is directly proportional to the factors of external influence, and the degree of risk, in turn, has a backward proportional dependence. The analysis of the quality assessment of the investment strategy allows us to 
draw certain conclusions: the sequence of calculation of parameters and coefficients, the obvious values of quality assessment at maximum / minimum values of the main parameters. In addition, the main factors that make up the external business environment are considered. The proposed assessment of the quality of the investment strategy is a flexible apparatus for modeling the results and potential directions of investment activity of the motor transport enterprise. The proposed method allows you to get an effective tool for analyzing investment strategy and is of practical importance for motor transport enterprises in the formation of an investment strategy.

Keywords: investment strategy, evaluation, influence factors, competitiveness, effectiveness, degree of risk, 3d model.

Постановка проблеми. Одним 3 основних етапів фрормування інвестиційної стратегії автотранспортними підприємствами є іiї оцінювання та визначення можливих наслідків при реалізації. Від коректної оцінки залежить не тільки результативність самої інвестиційної стратегії, а і ефрективний розвиток підприємства, і в деяких випадках його існування. При цьому інвестиційна стратегія, як частина загальної стратегії, може охоплювати різні напрями діяльності підприємства. Тому важко оцінити інвестиційну стратегію лише за одним узагальнюючим показником (критерієм). При оцінюванні слід враховувати не тільки загальну ефективність інвестиційної стратегії, а і ступінь ризику та вплив фракторів бізнес-середовища.

Аналіз останніх досліджень і публікацій. Серед науковців, які досліджують питання оцінювання інвестиційної стратегії існують різні підходи. Так, Р. Румельт [5] запропонував систему оцінювання стратегії, яка передбачає основним критерієм оцінки стратегії, тобто критерієм її якості, економічні результати розвитку підприємства, які характеризують ступінь досягнення підприємством своїх цілей. А.А. Томпсон та А.Дж. Стрікленд [7] відносять до основних критеріїв оцінки стратегії ступінь відповідності, перевага в конкурентні боротьбі, інтенсивність роботи. Також, набули поширення наступні підходи:

- аналіз можливих реакцій конкурентів;

- оцінка ризиків (технологічного, управлінського, зовнішнього);

- перевірка погодженості інвестиційної стратегії 3 місією підприємства;

- дослідження синергетичних есректів;

- оцінка здійснюваності стратегії [1];

- аналіз «розриву» (між цілями підприємств та його можливостями);

- аналіз динаміки витрат;

- оцінка відповідності між рядом нормативних та фрактичних показників економічного зростання, підхід запропонований Кіндрацькою Г.І. [4] та удосконалений Біловодською О.А. [2].

Кожен $з$ цих підходів має свої недоліки та переваги і може застосовуватися лише за пев- них умов і має ряд суттєвих обмежень. Більшість підходів передбачають можливість їх практичного використання лише для промислових підприємств, та/або виконання лише якісної, досить суб'єктивної оцінки стратегії. Це доводить необхідність фрормування авторського підходу щодо удосконалення методичних засад оцінювання інвестиційної стратегії автотранспортного підприємства.

Мета статті. Головною метою даної статті $\epsilon$ формування підходу щодо оцінювання інвестиційної стратегії автотранспортного підприємства, враховуючі певні критерії та фрактори впливу.

Виклад основного матеріалу. Аналіз і оцінка інвестиційної стратегії підприємства надзвичайно складна проблема, яка потребує як кількісних, так і якісних підходів. Він починається 3 моменту фрормування концепції такої стратегії, яка враховує мету, принципи, складові, задачі, цілі, узгодженість з загальною стратегією підприємства, його місією, визначає форми і методи техніко-економічного обґрунтування інвестиційних проектів, що потенційно можуть входити до інвестиційної стратегії та через які повинна бути досягнута мета цієї стратегії і $€$ елементами моніторингу в ході їх здійснення. При формуванні інвестиційної стратегії вирішальним етапом $€$ іiї аналіз та оцінювання. Враховуючи вищенаведене пропонуємо власний методичний підхід оцінювання інвестиційної стратегії в основу якого покладено визначення та оцінювання якості інвестиційної стратегії.

Якість - це фрілософрське поняття 3 термінології гуманітарних наук, до яких відноситься економіка. За визначенням Арістотеля якість - це побічна обставина, за допомогою якої річ $є$ якогось типу чи виду; побічна обставина, що вказує, якою є річ (ії змістовні якості та фрорми) і як річ діє (ії здатності та навички); побічна обставина, котра $€$ зовнішньою оцінювальною фрормою [3]. Якість - це сукупність характеристик об'єкта, які відносяться до його здатності задовольняти встановлені або передбачені вимоги. Таке визначення якості відноситься до виробництва товарів, 
надання послуг, процесів. Будь-яка продукція/ послуга/процес повинні відповідати певним вимогам споживачів. Рівень якості $€$ відносною характеристикою, що отримується при порівнянні значень показників якості даного об'єкта зі значеннями відповідних показників одночасно виготовлених зразків аналогічної за фрункцією продукції/послуги/процесу. Інтегральною мірою для оцінки якості (обладнання, машин, проектів, процесів тощо) служить абстрактна суспільно-корисна праця, збережена у наслідку їх використання при здійсненні виробничого процесу [6].

Таким чином, можна зробити висновок, що якість - це вища характеристична фрорма оцінки об'єкту/суб'єкту (товарів, послуг, процесів тощо), яка залежить та фрормується від параметрів, складових об'єкту/суб'єкту в які вкладена суспільно-корисна абстрактна праця. Праця може бути продуктивною, ефективною, дешевою, але в результаті товари/ послуги при цьому можуть бути неякісними.

Таким чином, узагальнюючи вищенаведене, запропоновано наступне визначення (definition) якості інвестиційної стратегії: якість інвестиційної стратегії - це оціночна характеристика інвестиційної стратегії, яка залежить від певних параметрів: ефрективності, рівня ризику, а також впливу фракторів макро-, мікрота мезосередовища (конкурентного середовища). При цьому, кожен 3 цих показників має інтегральне походження, тобто містить в собі залежність від відповідних одиничних параметрів. Слід зазначити, що ефективність (безризиковість, відсутність впливу фракторів середовищ) інвестиційної стратегії не означає автоматичну ії якість. Інвестиційна стратегія може бути ефрективною, але мати дуже високий ризик, або мати суттєвий вплив фракторів макро-, мікро- та мезосередовища (конкурентного середовища), що може унеможливлювати впровадження інвестиційної стратегії, тобто робить її неякісною.

Відповідно, якість інвестиційної стратегії може мати числове значення, яке буде залежати від інших інтегральних параметрів та відображати її рівень.

Таким чином, на думку автора, якість інвестиційної стратегії $\left(Q_{s}\right)$ залежить від двох основних параметрів: ефективності $\left(E_{s}\right)$ та ризику $\left(R_{\mathrm{s}}\right)$. Тобто математично можна визначити інвестиційну стратегію $\left(Q_{s}\right)$ як фрункцію, залежну від двох аргументів $\left(E_{s}, R_{s}\right): Q_{s}=f\left(E_{s}, R_{s}\right)$.

Очевидно, що якість інвестиційної стратегії прямо пропорційна її ефективності, тобто, чим вище ефективність інвестиційної стра- тегії, тим вище її якість. В свою чергу ефективність інвестиційної стратегії може бути обчислена, базуючись на відомих фрормулах розрахунку отримання економічного ефекту в майбутньому та фрінансових показниках автотранспортних підприємств.

Також очевидно, що якість інвестиційної стратегії зворотно пропорційна ризику при ії впровадженні. Тобто, чим вище ризик, тим менша якість інвестиційної стратегії. Рівень ризику також піддається обчисленню (може мати числове значення) використовуючи різні методи оцінки. При нульовому ризику (безризикова інвестиційна стратегія) якість буде прямо пропорційно залежати від її ефективності.

Крім того, при оцінюванні якості інвестиційної стратегії слід враховувати вплив важливих показників: макро-, мікро-, мезосередовища (конкурентного середовища). Ці показники, в свою чергу, можуть бути відображені у вигляді коефіцієнтів впливу (оцінок) з одного боку на ефрективність інвестиційної стратегії (прямо пропорційно, чим вища оцінка тим вища ефективність), 3 іншого боку на ризик (зворотна пропорційність, чим вища оцінка тим менший ризик). Як результат, коесріцієнти (оцінки) впливають на якість інвестиційної стратегії. Слід зазначити, що коефріцієнти впливу не $є$ сталими і можуть змінюватись у відповідності від загальної економічної ситуації як зовні, так і в середині підприємства на момент розрахунку якості інвестиційної стратегії. При цьому, коесріцієнти прямо пропорційні ефрективності $E_{s}$ (чим вище коефріцієнт, тим вище ефрективність), та зворотно пропорційні ризику $R_{s}$ (чим вище коефріцієнт, тим менший ризик).

Таким чином, математичну залежність можна визначити за наступною фрормулою:

$$
Q s=\frac{(a+b+c)}{3} * \frac{E_{s}}{1+\frac{3 R_{s}}{(a+b+c)}}=\frac{(a+b+c)^{2} * E s}{3(a+b+c)+9 R_{s}}
$$

де $Q_{s}$ - якість інвестиційної стратегії;

$E_{s}$ - есрективність інвестиційної стратегії, $0 \leq E_{s} \leq 1$;

$R s$ - ризик при впровадженні інвестиційної стратегії, $0 \leq R_{s} \leq 1$;

a - коефріцієнт впливу (оцінка) макросередовища, $0 \leq a \leq 1$;

$b$ - коесріцієнт впливу (оцінка) мікросередовища, $0 \leq b \leq 1$;

c- коефріцієнт впливу (оцінка) мезосередовища-конкурентного середовища, $0 \leq c \leq 1$.

Максимальне значення оцінки якості інвестиційної стратегії дорівнює 1, це означає, що безризикова інвестиційна стратегія, має мак- 
симальну ефективність $\left(E_{s}\right)$ та не має впливу чинників внутрішнього, зовнішнього, та конкурентного середовищ.

Слід зазначити, що кожен з аргументів фуункції, в свою чергу, являє собою інтегральний показник, який містить вплив інших показників при застосуванні системи експертних бальних оцінок та вагомих коефріцієнтів на кожен одиничний показник. Суттєвим недоліком бальних оцінок є суб'єктивність та вплив людського фрактору при оцінюванні. Практичний досвід діяльності автотранспортних підприємств показує, при любих методах оцінювання, включаючи бальний метод оцінювання, на кінцеве рішення при виборі як окремого інвестиційного проекту так і при затверджені загальної інвестиційної стратегії присутні суб'єктивність та вплив людського фрактору. Тому можна зробити висновок, що в даному випадку при застосуванні бальної системи оцінок експертами вплив суб'єктивізму на результат буде мінімальним. Крім того, кількість експертних оцінок прямо впливають на об'єктивність результату: чим більша кількість експертів задіяна при оцінюванні, тим менший вплив суб'єктивізму на кінцевий результат.

На основі вищенаведеного можна побудувати матрицю можливих значень якості інвестиційної стратегії в залежності від змінних параметрів $E_{s}$, та $R_{s} 3$ кроком дискретності 0.05 та коеоріцієнтів $a=b=c=1$.

Практичний інтерес являють значення якості інвестиційної стратегії, які переви- щують $0.5\left(Q_{s}>0.5\right)$. При цьому, як бачимо, що одне і теж значення Qs можна досягнути при різних значеннях $E_{s}$ та $R_{s}$. Це дуже важлива перевага при використанні цієї системи оцінки: можливість гнучкості при розрахунку цих інтегральних параметрів. При цьому, що чим менше значення якості, тим отримаємо більшу гнучкість системи. Гнучкість системи оцінювання якості інвестиційної стратегії при розрахунках має важливе значення при виборі як окремих інвестиційних проектів, так і при формуванні загальної інвестиційної стратегії.

Значення якості інвестиційної стратегії в залежності від ефективності та ризику при значенні коесріцієнтів впливу $a=b=c=1$.

Це дає можливість по-перше, використовувати більший діапазон показників та коефіцієнтів, при розрахунках майбутніх значень та моделюванні (прогнозуванні) різних ситуацій, а відповідно охоплює більшу кількість можливих/потенційних варіантів розвитку; по-друге, дає можливість обирати пріоритет між значеннями $E_{s}$ та $R_{s}$. Іншими словами, інвестори мають можливість більш свідомо та зважено приймати рішення щодо пріоритету основних параметрів інвестиційної стратегії (мати більшу ефрективність при меншому ризику, чи меншу ефективність при більшому ризику).

Використовуючи дані таблиці побудуємо тривимірну модель якості інвестиційної стратегії (рис. 1).

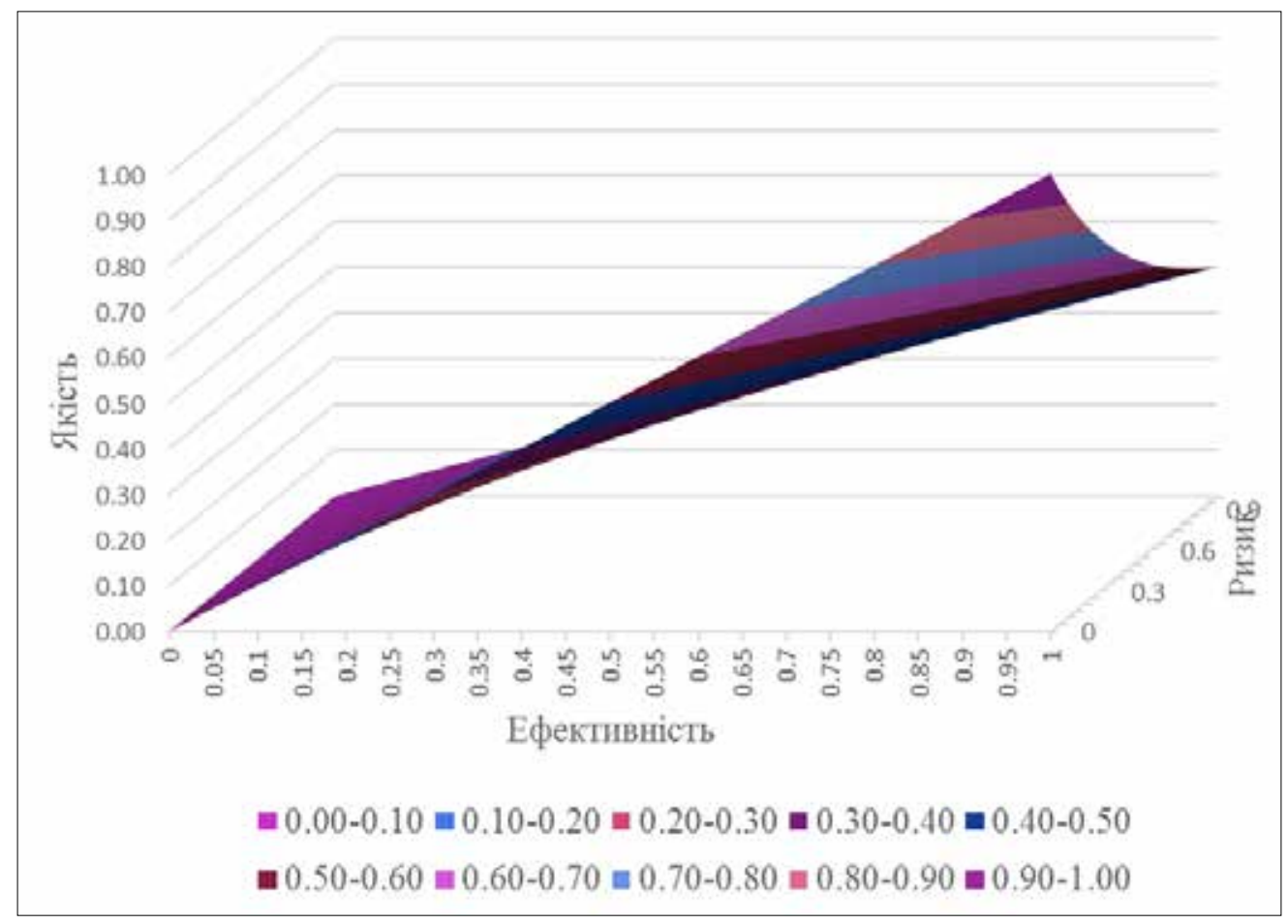

Рис. 1. Тривимірна модель оцінювання якості інвестиційної стратегії 
При оцінюванні якості інвестиційної стратегії можна зробити наступні висновки:

1. При нульовому значенні ризику $\left(R_{s}=0\right.$, безризикова інвестиційна стратегія) якість інвестиційної стратегії залежить тільки від ії едективності та коефріцієнтів впливу.

2. Максимальне значення ризику $\left(R_{s}=1\right)$ не відміняє формування та здійснення інвестиційної стратегії, але ії̈ якість зменшується вдвоє.

3. При нульовому значенні ефективності $\left(E_{s}=0\right)$ подальше фрормування та впровадження інвестиційної стратегії не має сенсу навіть при відсутності ризику та відсутності впливу коригуючих коефріцієнтів. Відповідно, як наслідок, розрахунок ефрективності має бути першим серед розрахунків інших параметрів та коефріцієнтів. Тобто, якщо результат розрахунку показує нульове значення ефрективності інвестиційної стратегії, то розрахунок інших параметрів та показників не має сенсу.

4. Одночасне нульове значення всіх коригуючих коефріцієнтів $(a=b=c=0)$ означає, що чинники впливу макросередовища, мікросередовища та мезосередовища (конкурентного середовища) блокують/унеможливлюють подальше формування та впровадження інвестиційної стратегії. Наприклад в умовах тривалої фрорс-мажорної ситуації (війна, природні катаклізми, глобальні терористичні події тощо) в регіоні здійснення інвестиційної стратегії, або в разі наявності судових справ 3 блокуванням діяльності автотранспортного підприємства. Відповідно, розрахунок коесріцієнтів впливу має бути наступним після розрахунку ефеективності інвестиційної стратегії. Крім того, при розрахунку коесріцієнтів слід ретельно аналізувати імовірність настання фрорс-мажорних/ неочікуваних ситуацій та розробляти відповідні заходи, що мінімізують негативний вплив на здійснення інвестиційної стратегії.

Як зазначено вище, ефективність інвестиційної стратегії - один з інтегральних параметрів якості інвестиційної стратегії. По суті оцінка ефрективності інвестиційної стратегії зводиться до оцінки ефективності обраних інвестиційних проектів, кожен 3 яких має власні розрахункові показники. Відповідно, використовуючи механізм бальної оцінки та коефіцієнтів питомої ваги на оцінку ефективності кожного проекту отримаємо загальну (інтегральну) оцінку ефективності інвестиційної стратегії.

Розрахунок коефріцієнтів впливу $(a, b, c) \epsilon$ наступним кроком після розрахунку ефрективності інвестиційної стратегії.
При розрахунку інтегрального коефріцієнту впливу макросередовища (а) запропоновано використати метод PEST-аналізу, який передбачає виділення чотирьох основних груп аналізу: політико-правові фрактори, економічні срактори, соціальні-географрічні срактори, технологічні фрактори. При цьому слід враховувати, що вплив кожного окремого фрактору можу бути як позитивним, так і негативним.

Перед розрахунком інтегрального коесріцієнту впливу мікросередовища (b) на якість інвестиційної стратегії автором визначено основні срактори, які впливають на інвестиційну діяльність автотранспортного підприємства: фрінансово-правові відносини 3 власниками підприємства, з постачальниками та партнерами, з клієнтами, з іншими суб'єктами господарювання (орендодавці, орендарі, сусіди, фріліали та окремі підрозділи підприємства і т.і.), корпоративна культура, внутрішня політика підприємства, бізнес-процеси підприємства, правові відносини 3 державою, контролюючи органи, кадрова політика підприємства. Кожен з цих фракторів має певний вплив на інвестиційну діяльність і, як результат, на якість інвестиційної стратегії. Чим вищий вплив окремого фрактору тим менша його розрахункова оцінка, що зменшує якість інвестиційної стратегії.

При розрахунку інтегрального коефріцієнту (c) впливу мезосередовища (конкурентного середовища) на оцінку якості інвестиційної стратегії запропоновано враховувати вплив наступних фракторів: існуючи конкуренти, конкурентоспроможність постачальників/продавців, загроза появи нових конкурентів, загроза появи нових конкурентних послуг/товарів, конкурентоспроможність самого автотранспортного підприємства, можливість клієнтів/ покупців, державна політика в сорері регулювання конкуренції.

Для розрахунку інтегрального показника рівня ризику $\left(R_{s}\right)$ при оцінюванні якості інвестиційної стратегії запропоновано використати комбінований метод, який буде поєднувати статистичний метод при розрахунку рівня ризику отримання очікуваних результатів (коесріцієнт варіації) та експертний метод при визначенні імовірності отримання результатів розрахунку показників інвестиційної привабливості.

Висновки. Підсумовуючи вищенаведене можна зробити висновок, що запропонований підхід щодо оцінювання інвестиційної стратегії являє собою ефрективну методику, яка математично враховує залежність якості інвестиційної стратегії від головних пара- 
метрів (есрективність та ступінь ризику) та фракторів впливу бізнес-середовища (макро-, мікро та мезосередовище/конкурентне середовище). Крім того, запропонована методика $\epsilon$ доволі гнучким інструментом, що дозволяє прогнозувати отримання певних результатів та об'єктивно обирати відповідні напрями розвитку діяльності підприємства. Це дає можливість практичного використання методики автотранспортними підприємствами при формуванні інвестиційної стратегії в умовах конкурентного середовища.

\section{СПИСОК ВИКОРИСТАНИХ ДЖЕРЕЛ:}

1. Берестенко В.И., Ломачинская И.А. Влияние прямых иностранных инвестиций на экономику Украины : матеріали міжн. наук.-практ. конор. «Постсоціалістичні країни в умовах світової фрінансово-економічної кризи». (Одеса, 24-25 квіт. 2009. Ч. 2) / ОНУ імені І.І. Мечникова, ред.кол. : С.О. Якубовський [та ін.]. Одеса : ОНУ.

2. Біловодська О.А., Сигида Л.О. Маркетингова політика розподілу: принципи управління та показники есрективності. Вісник Національного університету «Львівська політехніка». Логістика. № 846. С. 16-20. URL: http://nbuv.gov.ua/UJRN/VNULPL_2016_846_5

3. Вікіпедія. URL: https://uk.wikipedia.org/wiki/якість (дата звернення: 27.09.2021).

4. Кіндрацька Г.І., Кулиняк Ю.І., Загородній А.Г. Аналітичне забезпечення фрормування конкурентної стратегії організації. Вісник Національного університету «Львівська політехніка». Проблеми економіки та управління. 2013. № 754. С. 106-114. URL: http://nbuv.gov.ua/UJRN/VNULPP_2013_754_17

5. Румельт Р. Гарна стратегія, погана стратегія. Харків : Фабула, 2019. 324 с.

6. Студопедія. URL: https://studopedia.org/13-113066.html (дата звернення: 27.09.2021).

7. Томпсон А.А., Стрикленд А.Дж. Стратегический менеджмент. Создание конкурентного преимущества. Полное издание. 3-е изд. Москва : Диалектика, 2018. 800 с.

\section{REFERENCES:}

1. Berestenko V.I., Lomachinskaya I.A. (2009) Vliyanie pryamyh inostrannyh investicij na ekonomiku Ukrainy [Impact of foreign direct investment on the Ukrainian economy]: materialy mizhn. nauk.-prakt. konf. «Postsotsialistychni krainy v umovakh svitovoi finansovo-ekonomichnoi kryzy». (Odesa, 24-25 kvit. 2009. Ch. 2) / ONU imeni I.I. Mechnykova, red.kol.: S.O. Yakubovskyi [ta in.]. Odesa: ONU.

2. Bilovodska O.A., Syhyda L.O. (2016) Marketynhova polityka rozpodilu: pryntsypy upravlinnia ta pokaznyky efektyvnosti [Distribution marketing policy: management principles and performance indicators]. Visnyk Natsionalnoho universytetu "Lvivska politekhnika". Lohistyka, no. 846, pp. 16-20. Retrieved from: http://nbuv.gov.ua/UJRN/ VNULPL_2016_846_5

3. Wikipedia. Retrieved from: https://uk.wikipedia.org/wiki/yakist (accessed 27 September 2021).

4. Kindratska H.I., Kulyniak Yu.I., Zahorodnii A.H. (2013) Analitychne zabezpechennia formuvannia konkurentnoi stratehii orhanizatsii [Analytical support for the formation of the competitive strategy of the organization]. Visnyk Natsionalnoho universytetu "Lvivska politekhnika". Problemy ekonomiky ta upravlinnia, no. 754, pp. 106-114. Retrieved from: http://nbuv.gov.ua/UJRN/VNULPP_2013_754_17

5. Rumelt R. (2019) Harna stratehiia, pohana stratehiia [Good strategy, bad strategy]. Kharkiv: Fabula, 324 p.

6. Studopediia. Retrieved from: https://studopedia.org/13-113066.html (accessed 27 September 2021).

7. Tompson A.A., Striklend A Dzh. (2018) Strategicheskij menedzhment. Sozdanie konkurentnogo preimushchestva [Strategic management. Building a competitive advantage]. Polnoe izdanie. Moscow: Dialektika, 3-e izd. 